DOI: https://doi.org/10.32839/2304-5809/2020-4-80-42

UDC 811.133.1'42:659.4

Devos Anastasiia

Institute of Philology,

Borys Grinchenko Kyiv University

\title{
GENDER ASPECT OF SOCIO-CULTURAL REPRESENTATIONS IN ADVERTISING DISCOURSE
}

Summary. This article is devoted to the study of the gender aspect in socio-cultural representations, including its role, functions and features used in the creation of the French advertising discourse. In the article according to these criteria, the lexical, syntactic and phonetic levels of the advertising discourse are presented, where gender variations can be traced more clearly. Sociolinguistic elements consider the basis for the creation of socio-cultural representation. They include aspects such as age, gender and class identity. Representational content and nature of advertising vary depending on these aspects, also its pragmatic orientation. For example, advertising of children's products appeal to their young customers with stories and images of cartoon characters, but in advertising for adults, a main character is a successful family man. However, many scientists agreed that gender dimension serves as a major sociolinguistic element in the creation of advertising discourse. Keywords: gender aspect, kognem, advertising discourse, sociolinguistics, socio-cultural representation, and stereotype.

Девос А.O.

Інститут фрілології

Київського університету імені Бориса Грінченка

\section{ГЕНДЕРНИЙ АСПЕКТ СОЦІОКУЛЬТУРНИХ РЕПРЕЗЕНТАЦІЙ У РЕКЛАМНОМУ ДИСКУРСІ}

Анотація. Стаття присвячена вивченню гендерного аспекту соціокультурних репрезентацій, а саме його ролі, функцій та особливостей використання при створенні фрранцузького рекламного дискурсу. Відповідно до цих критеріїв у статті розглянуті лексичний, синтаксичний та фонетичний рівні рекламного дискурсу, оскільки тут гендерні варіювання прослідковуються найчіткіше. Соціолінгвістичні елементи становлять невід'ємну частину створення сощіокультурних репрезентацій. До них відносяться такі аспекти як вік, стать та класова приналежність. Залежно від цих аспектів варіюеться зміст та репрезентаційний характер реклами, їі прагматична спрямованість. Наприклад, реклама дитячих товарів апелює до своїх юних споживачів образами із казок та мультиплікативними героями, натомість у рекламі для дорослих головний персонаж - це успішна, самореалізована сімейна людина. Однак, основним соціолінгвістичним елементом, на нашу думку, виступає гендерний аспект, оскільки фрактор статі є головним при створенні рекламного дискурсу. Соціокультурні репрезентації не тільки відтворюють, а й посилюють образи гендерного світу. Вони створюють заряджену певним гендерним значенням символіку, що належить до тієї чи іншої статі. Діапазон можливого вибору е досить широким: образи супержінки і суперчоловіка, традиційної жінки, і так далі, демонструють реципіентам, які шанси чоловіків і жінок у домінуванні та владних структурах. Це дає рекламі додатковий потенціал впливу на аудиторію, якою є весь соціум. Рекламодавці “продають” споживачу суспільно визнану версію соціального світу і відносин у ньому. Слід підкреслити, що під час розробки реклами найбільш активно обробляеться “жіноча” складова, тому що саме жіноча аудиторія є основною мішенню реклами як найбільш імовірні покупці. Жінки розглядаються як група, що більш підвладна рекламному впливу. Говорячи про рекламний дискурс, ми дотримуємось точки зору, що соціокультурні репрезентації спираються на існуючі гендерні стереотипи, оскільки колективна свідомість стереотипна. Саме стереотипи, у тому числі й гендерні, відіграють суттеву роль під час впливу на свідомість індивідів, на їх уявлення про світ, тому що вони серйозно впливають на внутрішню готовність людини певним чином сприймати явища оточуючого світу, ощінювати їх і діяти щодо них.

Ключові слова: гендерний аспект, когнема, рекламний дискурс, соціолінгвістика, соціокультурна репрезентація, стереотип.

dvertising has rapidly entered to the life of Amodern society and has become an integral part of it. Advertising is used in almost all areas of human activity. For nearly a century, advertising has been an object of research of sciences such as linguistics, psychology, sociology, cultural studies, and philosophy and so on.

From the point of view of philology advertising is a particular sphere of practical human activity which main product is advertising text that really matters for linguists. However, except of the text, every advertising message has a socio-cultural representation on its basis. These representations play a very important role in the creation of the adver- tisement and are affected a lot by the gender factor. That is why in this research, we decided to focus on studying the gender aspect of socio-cultural representations in the advertising discourse.

In addition, it should be noted that the term of "socio-cultural representation" is relatively new for the post-Soviet scientific literature, so during our study we only used foreign sources [Auger 2003; Boyer 2003, 2007].

To begin with, we would like to explain the concept of socio-cultural representations. Famous sociologist Emile Durkheim introduced this concept in the late nineteenth century. Durkheim noted that our social life consists entirely of representations. 
He developed the idea of dominance of collective stereotypes in society [3, p. 19].

For Durkheim socio-cultural representations were established stereotypes and concepts that appear in people's subconscious, attributing an individual to a particular socio-cultural community. He mentioned that society produces certain representations, which over time are accumulated in the human mind and then are firmly fixed in it. They can have historical, ideological or religious roots and are based on the experience of past centuries.

His successor Serge Moscovici in his research focuses on the fact that the set of representations of the culture of any country is indivisible whole, which cannot be decomposed into separate ideas. Since the 1960s, thanks to S. Moscovici, the concept of socio-cultural representations has been gaining popularity in social psychology. In his works Moscovici underlines that normal human existence outside of the society is impossible: "Individual is nothing without society which develops their mind and gives them right to deploy their own activities, dreams and destiny" [3, p. 22-23].

Another scientist who made a big contribution to the development of the concept of socio-cultural representations was French researcher D. Jodlais. He claimed that "socio-cultural representation is a particular form of knowledge, created and developed by the society. It has practical character and generally resorts to construct social realities in the community". In his view, social and cultural representations serve to influence the surrounding world [3, p. 32].

Another French researcher P. Bourdieu shared the point of view of Jodlais. For Bourdieu socio-cultural representations were "performative sayings whose goal is to clarify the fact that they express" $[3$, p. 46]. In his works dedicated to the study of socio-cultural representations, Bourdieu pointed out the importance of standardized meta-system, which serves as the basis of any representational activity. The researcher explained the definition of meta-system as following: "meta-system is a set of public perceptions and common ideas that includes the analysis of these ideas, which are actually the object of study within socio-cultural representations" [3, p. 47].

In their scientific studies, many researchers identified the concept of socio-cultural representations with such concepts as "attitude", "imagination", "stereotype" and "image". However, we support the point of view of Moscovici, who notes that the concept of socio-cultural representations is much broader and includes all above-mentioned concepts.

Moscovici highlights certain features that characterize each socio-cultural representation and calls them "cognems". He divides these cognems into two groups. The first group contains cognems that form the core of each representation. They provide stability to representation and its semantic content is based on them. In addition, the central core has a dual role: evaluative and pragmatic.

To the second group refer minor or peripheral cognems that, in the opinion of Moscovici, are optional, because they vary depending on the associations provoked by the representation, its contextual features and implicit meaning. Thanks to these peripheral cognems each socio-cultural representa- tion can adapt to any field of human activity and gain a foothold in it later [4, p. 23]. In our opinion, these peripheral cognems are mostly affected by the influence of the gender factor.

It is necessary to emphasize that the meaning of socio-cultural representations should be taken into consideration during the creation of an advertising message in the advertising discourse. Values and stereotypes that form the basis of each representation are spread in the society through advertising. So, advertising discourses serve as a reflection of socio-cultural representations of the society.

It should be noted that sociolinguistic elements play an important role in creation of socio-cultural representation. They include aspects such as age, gender and class identity. Representational content and nature of advertising vary depending on these aspects, also its pragmatic orientation. For example, advertising of children's products appeal to their young customers with stories and images of cartoon characters, but in advertising for adults, a main character is a successful family man. However, in our opinion, gender dimension serves as a major sociolinguistic element in the creation of advertising discourse.

Sociologist O. Maximova defined the advertising as "one of the most aggressive gender technologies". In her opinion, socio-cultural representations in advertising discourse are symbolic reproductions of femininity and masculinity that also convey information about the character of interpersonal relationships between men and women [2, p. 246].

Socio-cultural representations not only reflect but also reinforce gender images in the world. They create values charged by certain gender symbols belonging to a particular sex. The range of the selection is rather wide: superman and superwoman images, traditional family woman image, and so on, show to recipients what chances of men and women in positions of power and dominance are. It provides to advertising an additional impact on the audience, which is the whole society. The Advertiser "sells" to his consumer widely recognized versions of the social world and the relationships within it.

It should be emphasized that during the creation of advertising, the female part is most actively processed, because the female audience are the most likely buyers. Women are considered as a group that is more affected by advertising.

Talking about the advertising discourse, we uphold the view that socio-cultural representations are based on existing gender stereotypes, because the collective consciousness is stereotyped a lot. All stereotypes, including gender, have a significant impact on the minds of individuals, their view of the world, because they seriously affect the human inner readiness to perceive the phenomena of surrounding world.

According to the interpretation of A. Kirilina, gender stereotypes are "culturally conditioned ideas and presupposition about qualities, attributes and norms of behavior of both sexes, which are reflected in the language" [1, p. 47].

Studying the lexical aspect of socio-cultural representations from the part of gender stereotypes, we can emphasize that there are traditional feminine traits, for example, women are considered to be soft and emotional, and traditional male traits 
such as rationality, activity and desire to dominate. That is why texts of female advertisements are rich on emotional and evaluative vocabulary, especially on adjectives related to the image of an attractive, active and successful woman. The reason for this statement is based on the opinion of psychologists that women are more focused on their inner world than men are, and therefore use more words that express the emotional and mental states.

In terms of gender analysis, particular attention gains a metaphor, because, according to the researchers, especially female language is rich on them. Metaphors are a favorite stylistic device in advertising of cosmetics. Using of metaphor expands the vocabulary of the word and increases its expressive content. In the language of women, more often than in language of men are used such tropes as comparison, hyperbole and epithet.

Quite clearly we can trace the usage of metaphor in advertising of woman's lip gloss l'Oréal. In order to motivate potential buyers to buy a new lipstick of l'Oréal, advertisers portray a man who passionately wants to kiss a woman, but she resists. This picture is accompanied by the slogan: "Test the persistence!" which has the double meaning. This slogan we can interpret as an appeal to test the persistence of the new lip-gloss, or to test the man who can not resist the kiss, seeing her lips shining.

Another example of usage of such stylistic device as a hyperbole we can observe in advertising campaign of trademark Clarins, launching the new series of suntan products. On its poster we can see a man holding a woman in his hands, because he can not stand against her bronze skin. This picture is accompanied by the slogan: "Sun could never make better".

It should also be noted that women more than men tend to use the diminutive suffixes. This property is a particular characteristic of female speech style. Application of this method which effect is amplified by alliteration (repetition of the same consonant sounds) gives to advertising discourse gentle sound.

In advertising, women's goods advertisers use stylistic alliteration of the soft consonants $-m,-l$. Any sound of the human voice and even every letter by itself can cause in the human mind definite ideas, associations, images. For example, human imagination associates the sound $-l$ with something smooth and easy, and sound $-m$ with something sweet, soft, gentle, short. These sounds provoke pleasant associations as words mother, merry. In this case, the creators of female advertising discourse use the stereotype that purely women features are softness and tenderness. Therefore, on the phonetic level in female advertising discourse we can observe alliteration of soft consonants, and in male advertising discourse alliteration on hard consonants.

A bright example of alliteration in female advertising is, in our opinion, the slogan of French company "Le Manège à Bijoux": "If Prince Charming is looking for $\boldsymbol{m e}$, he knows where to find $\boldsymbol{m} e^{\text {". }}$

In advertisements of men's products, we can also find evaluative adjectives, which are rather stylistically neutral and do not express any emotions, but primarily describe the basic qualities of the product. We can trace it in the advertising campaign of famous Japanese car manufacturer Mitsubishi. While presenting their new model of the Pajero Sport, they place the car next to a sumo wrestler. Sumo wrestler in Japanese culture represent the power, and we all know that Japanese cars are among the most powerful and reliable in the world. This interpretation convinces a consumer in a high quality of the product. This advertisement is accompanied by the slogan: "MITSUBISHI PAJERO EDITION EXCLUSIVE X-STORM MONSTROUSLY OVEREQUIPPED". Thus, we see that the adjective "overequipped" describes the basic qualities of the product and it is at the same time brief but polysemantic.

Therefore, we can conclude that according to the creators of advertising, men are more eager for rationality, while women focus on their emotions and feelings, so there are differences in the use of language. Advertisers appeal to women's feelings and emotions, because they know that women are primarily focused on their appearance. However, men are mostly interested in the direct product qualities, they are more practical and rational while choosing a product and do not give into emotions. Socio-cultural representations of advertising products for men appeal to such masculine qualities as courage, strength, vigor, sporty, self-confidence, stamina and charisma. Lexical means of advertising of cosmetic goods for women are more metaphorical, expressive, emotionally labeled and vocabulary of advertising products for men is more clear and concise.

Nevertheless, not only the vocabulary of advertising discourse, syntax tools also vary depending on the gender factor. First, it should be noted that the first scientist who drew his attention to the fact that women and men build their sentences differently was O. Jespersen. For example, in the speech of men we can meet complex, confusing but short structures, that Jespersen called "ragged syntax" [6, p. 45].

Explaining the point of view of Jespersen, English linguist P. Smith wrote that men usually introduce one sentence into another, put one in the other [7, p. 56]. Moreover, women's syntax is like "a line of pearls" in which pearls are strung closely together. In the women's speech there is, in addition, fusion of syntactic structures and they often use inversion and ellipsis.

Advertising texts of women's goods are wider, while advertising texts of men's products mainly consist of simple, concise sentences. "Female" syntax is characterized by sentences with homogeneous members with lots of qualitative adjectives. This method indicates that women pay more attention to various small parts and they need more different qualities of the product to be presented. Moreover, verbosity and triviality are traditionally considered as the attributes of women's style of communication. While texts of men's advertising are brief and concise.

The simplicity and brevity of advertising slogans for men we can clearly see in the advertising of men's perfume Azzaro. Perfume Company Azzaro while promoting on the market a new fragrance for men called "Chrome", appeals to the socio-cultural representation of generation unity. On their poster they drew a picture of happy family, which consists of father, son and grandson, accompanied by the words "AS LONG AS MEN EXIST..." Sim- 
plicity and brevity of this slogan indicates that the creators of male advertising are familiar with the specifics of male thinking. Advertisers emphasize the fact that men are main successors of the family, and if not men, life on the earth will stop. And the real men use only perfumes of Azzaro.

Summarizing all the above, we can assert that the socio-cultural representations of advertising discourse are deeply influenced by gender factor: the advertising discourse is full of gender stereotyped judgments about the fact that women are primarily focused on their appearance, while men are mainly focused on the activity and the desire to succeed in life. Typical female features are emotionality and expressiveness and typical male features are neutrality and rationality. Gender variations of socio-cultural representations occur at lexical, syntactic and phonetic levels of advertising discourse.
Therefore, we came up with the conclusion that the advertising discourse of women's products is characterized by the usage of tropes (metaphors, hyperbole and comparisons), evaluative adjectives and names of colors (particularly specific). In the texts of male advertising we can also observe the usage of the evaluative adjectives, but those that define the concrete product qualities. At the syntactic level texts of female advertising are characterized by the widespread usage of inverted word order, ellipses and exclamation sentences. Sentences from female advertising messages are more widened at the syntactic level, while the sentences from male advertising have direct order of words and usually are very short. In addition, the phonetic level gender variations are determined by the prevalence of the soft consonants in female advertising discourse and of hard consonants in male advertising.

\section{References:}

1. Kirilina A.V. Gendernyie aspektyi massovoy kommunikatsii. Gender kak intriga poznaniya : sb. st. M., 2000. S. $47-80$.

2. Maksimova O.B. Gendernoe izmerenie v sovremennom sotsialno-kommunikativnom diskurse: rol reklamyi. Vestnik RUDN. Seriya : Sotsiologiya. 2004. № 6-7. S. 246-254.

3. Auger N. LES RÉPRÉSENTATIONS INTERCULTURELLES EN DIDACTIQUE DES LANGUES-CULTURES Enquêtes et analyses / N. Auger, P. Cardies, E. Kotul, M.- Carmen Alén Garabato. Paris : L’Harmattan, 2003.127 p.

4. Boyer H. DE L'AUTRE CÔTE DU DISCOURS Recherches sur les représentations communautaires / Henry Boyer. Paris : L'Harmattan, 2003. 124 p.

5. Boyer H. STEREOTYPAGE ET STEREOTYPES: fonctionnnements ordinaires et mises en scène Tome 1 MEDIA(TISATION)S / Henry Boyer. Paris : L'Harmattan, 2007. 298 p.

6. Jespersen O. Language: its nature, development and origins / O. Jespersen. London : Penguin Books ltd, 1922. $320 \mathrm{p}$.

7. Smith P. Language, the sexes and society / P. Smith. Basil : Longman, 1985. 432 p. 